\title{
Economic Loss Estimation in the Context of Country's Economy
}

\author{
Zaneta Simanaviciene ${ }^{1}$, Oksana Palekiene ${ }^{2},{ }^{1-2}$ Kaunas University of Technology, \\ Illya Khadzhynov, Donetsk National University
}

\begin{abstract}
The economic decline in the period of economic downturn affects social and economic development of the country's regions. In this paper economic loss incurred is understand as amount of forgone income in the period of economic downturn. The presented methodology allows to objectively access economic losses and to identify which country or region suffered most from the economic crisis. The methodology presented in the paper is based on the dynamics of actual economic indicator - GDP change.
\end{abstract}

Keywords: Regional development, economic crisis, economic loss, social and economic development indicators.

\section{INTRODUCTION}

World global crisis, which started in 2007 and gradually evolved from the financial to the economic sphere in 2008 , affected the majority of world's economies. The current global crisis differs from the past crises in terms of its scale and propagation speed. This was conditioned by globalisation and growing global economies, as integration in financial, cultural and other spheres has had an impact on the spread of economic problems around the world.

In the period of slowdown of the country's economic growth, the economic indicators significantly worsen, for example, some consequences are demographic deterioration, increase of the cost of living, budget deficit, asset price inflation, decrease in internal and external demand, growth of unemployment, real income decline, decline in production and trade and investment levels, etc. Slowdown of gross domestic product (GDP) growth has become one of the most prominent indicators of the economic crisis. The economic losses incurred by the countries in the period of the economic downturn (2007 - 2009) are manifold, so financially the quantitative expression of the economic loss with respect to the country's economy can be assessed only when the country recovers from the economic downturn.

The economic downturn in Lithuania has a negative impact on the national social economic development. The economic decline in the period of economic downturn affects social and economic development of all country. In order to determine the main fluctuations in the country's economy, various indicators are used, namely, statistical indicators, the dynamics of which define the economic situation of the country. Performing the analysis of the main social and economic indicators characterizing the state of the country, it could be stated that GDP is the key indicator, which has an impact on all other macroeconomic indicators.
In this paper the impact of the economic crisis on different economies is understood as a comparison of the realized possibilities with the lost ones. In other words, economic loss incurred by each country in the period of economic downturn can be estimated by comparing the actual economic situation with the one that would have occurred if the economic downturn had not started at all. In this paper economic loss is defined as amount of forgone income in the period of economic downturn. As GDP is the key indicator of social and economic identification of a country, exactly the GDP indicator is the main component of the economic loss estimation methodology presented in the paper.

The main objective is to elaborate the methodology for economic loss estimation in the period of economic downturn.

Object: Economic loss.

Methods: in order to distinguish and methodically assess the economic losses incurred due to economic crisis, comparative, systematic, and logical analyses of scientific literature and generalization, mathematical and statistical methods are used.

Implementation of the proposed economic loss estimation methodology in the period of economic downturn will determine the extent and nature of the impact of economic crisis on the development of the national economies of Lithuania and Ukraine. The methodology presented in this paper allows to objectively access economic losses and to identify which country or region suffered most from the economic crisis. The most prominent economic crisis indicators are estimated and analysed. Economic losses incurred by Lithuania and Ukraine are estimated and compared.

\section{ANALYSIS OF THE MAIN MACROECONOMIC INDICATORS}

Economic welfare of each region is closely related to the economic development of the country. The differences of economic growth in the long-terms determine the unequal country's development level and the standard of living. In 2008 Lithuanian economy started slowing down, economic growth began to fluctuate. In order to evaluate the fluctuation magnitude and its frequencies, various indicators are used in the economic literature, in other words - statistical indicators, which show the dynamics of the situation in the economy.

The key indicators defining the development and economic situation of the national economy in economic literature are presented and described in a similar way. Nevertheless, some scientists in order to perform the analysis of economic situation suggest analysing the economic cycles and indicators determining their phases [2], [15], [27]. Other scientists make 
a great focus on the concept of the economic crisis; they suggest performing analysis of their determinants and crisis consequences [7], [14].

Many scientists confirmed that the most important indicators determining the state of a country's economy are GDP, employment, unemployment rate, level of domestic consumption and investments, the current account deficit, the country's budget deficit, imports/exports, interest rates, inflation, official international reserves, the situation on the real estate and stock markets [10], [12], [24], [28]. Rötheli and Tobias (2007) argued that it is necessary to add two more indicators to the above mentioned: standard of living and level of poverty indicators [27].
Pukelienè, Glinskienė and Beržinskienè (2007) as one of the main indicator marked labour migration indicator, which occurs as a response to the labour demand and supply disproportion, as well as mismatch of wages between different regions [29]. Blümle and Goldschmidt (2006) identify three indicators - unemployment rate, standard of living and production volumes, which characterize the economic situation in the country best [27]. Economists released one more indicator, which actually reflects the growth of GDP consumer confidence index, which reflects the financial situation of the average client, their purchasing power and confidence.

TABLE I

ANALYSIS OF THE MAIN MACROECONOMIC INDICATORS IN THE PERIOD OF ECONOMIC DOWNTURN

\begin{tabular}{|c|c|c|}
\hline Indicator & Indicator analysis & Index \\
\hline GDP & $\begin{array}{l}\text { Declining GDP promotes the decline of real estate prices, as usually the country's economy } \\
\text { during the economic downturn is in decline, consumer purchasing power decreases, shrinking } \\
\text { credit, which reduces the demand for real estate. }\end{array}$ & $\begin{array}{l}\text { Annual Real (Actual) GDP } \\
\text { Change }\end{array}$ \\
\hline Inflation & $\begin{array}{l}\text { Declining inflation reduces fixed-income consumer purchasing power, as a results real wages } \\
\text { and standard of living fall. During the recession many companies lose profits, some grow } \\
\text { relatively slowly, salaries are not increased, purchasing power is reduced and entrepreneurs } \\
\text { have to forget about raising output prices. So, the lower is GDP, the lower is the inflation in the } \\
\text { country. Inflation is closely related to the basic interest rates. Central Bank increasing the base } \\
\text { interest rate, stops borrowing, reduces consumption and economic growth, and therefore } \\
\text { inflation is also decreased. }\end{array}$ & $\begin{array}{l}\text { Annual Inflation/ Harmonized } \\
\text { Index for Consumer Price }\end{array}$ \\
\hline Employment & $\begin{array}{l}\text { Along with market demand declining, the number of orders decrease, the usual volume of } \\
\text { income is no longer received. The company fires employees because it cannot employ them } \\
\text { anymore, reduction in demand leads to decrease of employment. With increasing } \\
\text { unemployment purchasing power of population decreases, because a lesser part of the society } \\
\text { receives income. A vicious circle is: employees are fired because of declining demand, and the } \\
\text { demand decreases because the fired employees cannot afford buying goods and services. } \\
\text { Unemployment rate and GDP are closely related: the more workers are employed, the more } \\
\text { services and products are produced. Along with unemployment declining, GDP decreases. } \\
\text { Unemployment is closely related to the basic interest rates. When unemployment is rising, } \\
\text { reduction of interest rates is generally expected. }\end{array}$ & $\begin{array}{l}\text { Average Monthly Gross Wage } \\
\text { Change/ Average Annual } \\
\text { Unemployment Rate }\end{array}$ \\
\hline Basic Interest Rates & $\begin{array}{l}\text { With decline in consumption, the amount of money in the economy decreases, the base interest } \\
\text { rate increases. Raising the basic interest rates, the amount of money in the market decreases and } \\
\text { the decline in the money supply raises the prices (i.e. raising basic interest rates, the national } \\
\text { currency in comparison with foreign currencies becomes more expensive. Such situation } \\
\text { encourages imports and current account deficit. }\end{array}$ & Percentage \\
\hline $\begin{array}{l}\text { State Budget } \\
\text { Deficits and Public } \\
\text { Debt Levels }\end{array}$ & $\begin{array}{l}\text { The increasing or non-decreasing state budget deficit could lead to public debt that threatens the } \\
\text { country's macroeconomic stability. Large public debt means that the country must reduce } \\
\text { spending and start saving. Lower consumption is an unfavourable condition for business. The } \\
\text { higher is the level of public debt, the worse are business conditions in the country. Growing } \\
\text { public debt reduces the country's ability to borrow. }\end{array}$ & $\begin{array}{l}\text { Total Public Debt, Total Public } \\
\text { Debt Service Rate, Total Gross } \\
\text { Public Debt as a Percentage of } \\
\text { GDP [1] }\end{array}$ \\
\hline $\begin{array}{l}\text { Current Account } \\
\text { and Trade Balance } \\
\text { of the Country }\end{array}$ & $\begin{array}{l}\text { If the country imports more than it exports, current account deficit is generated, i.e. the country } \\
\text { follows the money. In order to continue the use, citizenry, companies and the country are forced } \\
\text { to borrow. The deficit of current account affects currency value. With increasing current } \\
\text { account deficit the national currency depreciates. With declining in currency value in the } \\
\text { country, inflation increases, because the prices for imported goods and raw materials get } \\
\text { instantly raised. }\end{array}$ & Monetary Unit \\
\hline $\begin{array}{l}\text { Consumer } \\
\text { Confidence }\end{array}$ & $\begin{array}{l}\text { With decrease in sales consumption also declines. The lower consumer confidence and } \\
\text { expenditure is, the less output the country creates and GDP declines. }\end{array}$ & $\begin{array}{l}\text { CB Consumer Confidence, } \\
\text { Business Sentiment Index }\end{array}$ \\
\hline
\end{tabular}

Summarizing all scientific and economic approaches to the main indicators describing economic situation in the country, we could state that GDP is a key indicator, which affects all other macroeconomic indicators. According to Westermann and Tornell (2002), the exact GDP accounting allows solving two interrelated problems: determine the state of the economy (production decline or rise, and at what pace) and reveal the number of relations between the production and unemployment rate, price level, income and so on, and to evaluate the effectiveness of economic policies [13].

As the macroeconomic indicators have a significant impact on savings, investment, consumer spending and other actions of individual entities, imbalances occurs in the whole structure of demand system. Due to economic downturn, the possibilities of the regions and their income vary significantly. Sufficiently distinct socio-economic territorial differences are 
observed among the regions. Country policy, comparing regional social and economic differences, can suppress them, but it is quite difficult to perform this action in the period of the economic downturn.

\section{ECONOMIC LOSS ESTIMATION}

Regional economy and its development are determined by more or less numerous interrelated factors and conditions. The economic downturn has a negative impact on the national social economic development of each country. The crisis has inevitably led to reduction of many of regional development main indicators (Table 1). In order to objectively evaluate the economic loss incurred by the regions, it is appropriate to implement economic loss estimation methodology after the analysis of economic crisis risk factors, features and outcomes. The methodology presented in the paper is based on the dynamics of a real economic indicator - GDP change.

In this paper the impact of the economic crisis on different economies is understood as a comparison of the realized possibilities with the lost ones. In other words, economic loss incurred by each country in the period of economic downturn can be estimated by comparing the actual economic situation with the one that would have occurred if the economic downturn had not started at all. In this paper economic loss is defined as amount of potential income that has never been earned or that would have been earned during a specific period of time, which could not have been earned as a result of a specific event.

Since economic crisis is usually conceived by losses in GDP, the performed approach is based on comparing real GDP during the crisis period with some estimate of potential output. It estimates potential output assuming that the output would have grown at the same constant rate based on its past performance [6], [11], [20], [22], [25], [26]. The output loss (lost income) is defined by the analysis of the pre-crisis tendency of economy development, which allows in the future receive a forecasted (predicted) output value and real growth rates.

Constructing output loss measures, a number of issues should be analysed [4], [5], [9], [16], [17], [19], [20], [22]:

1. Defining the beginning and end of the crisis;

2. Estimation of output during the crisis period in the absence of crisis;

3. Measuring output losses: levels versus growth rates;

4. Alternative methods used in measuring output losses.

Using the output loss estimation approach, total output losses are understood as the difference between actual and potential output over the duration of the respective crisis. The value of lost income is determined by analysis of the pre-crisis development trend of each economy. The presented economic loss estimation methodology consists of the following steps:

Step 1. Defining the beginning of the economic crisis (an economic crisis is defined as a negative growth during two consecutive quarters);

Step 2. Calculation of potential output indicator by using linear trend

$$
Y_{t}=b_{0}+b_{1} \cdot t
$$

where $Y_{\mathrm{t}}$ - indicator of output in value terms per year t; $t$ - time;

$b_{0}$ and $b_{1}-$ calculated parameters.

Step 3. Calculation of real growth rate, which characterizes percentage variation of actual GDP of each following year in comparison with the previous ones, in other words, it indicates the growth rate of GDP

$$
g=\left[\left(Y_{t}-Y_{t-1}\right) / Y_{t-1}\right] \cdot 100 \%
$$

where $Y_{\mathrm{t}}-$ real GDP of the previous $\mathrm{t}$ year;

$g-$ the real growth rate in year $\mathrm{t}$ (in percent).

Step 4. Calculation of growth rates for situation without crisis (for $100 \%$ actual level of growth rate the level of 2006 or other year is accepted, depending on the country).

Step 5. Calculation of lost income value. The calculated growth rates indicators for 2007-2009 situations without crisis are compared with the calculated growth rates based on the actual growth rate. The difference between these two indicators determines lost income value, i.e. economic loss incurred due to the economic crisis. This value is expressed as a part of country's GDP.

$$
I_{\% G D P}=\left[\left(Y_{t}^{e}+Y_{t}^{a}\right) / Y_{t}^{a}\right] \cdot 100 \%
$$

where $Y_{\mathrm{t}}^{\mathrm{e}}$ - estimated (predicted) GDP expected in year $t$ before the crisis;

$$
Y_{\mathrm{t}}^{\mathrm{a}}-\text { actual GDP in year } t \text {. }
$$

\section{RESEARCH RESULTS}

As the peak of economic downturn occurred in 2009, this year is chosen for performing the calculation of economic losses incurred by Lithuania and Ukraine. Real GDP data is taken from the World Economic Outlook database [18]. The level of year 2006 is taken as growth rate of $100 \%$ level.

Comparing the results of analysis of Lithuanian and Ukrainian situation in the period of economic downturn, it is noticeable that they are very similar (Table 2 ).

TABLE II

PRE-CRISIS TENDENCY PERFORMANCE

\begin{tabular}{|l|l|l|l|}
\hline & $\begin{array}{l}\text { Real } \\
\text { growth rate } \\
\text { for 2009 } \\
\text { (WEO) }\end{array}$ & $\begin{array}{l}\text { Estimated pre-crisis } \\
\text { tendency (calculations } \\
\text { performed by authors) }\end{array}$ & $\begin{array}{l}\text { Pre-crisis } \\
\text { tendency for } \\
\text { 2009 (IMF) }\end{array}$ \\
\hline Ukraine & -15.1 & 6.4 & 4.2 \\
\hline Lithuania & -14.8 & 6.2 & 5.5 \\
\hline
\end{tabular}

Based on pre-crisis tendency by IMF, the economy of Ukraine should have grown by $4.2 \%$, whereas the economy of Lithuania - by $5.5 \%$. With the reference to the calculations performed by the authors, the economy of Ukraine should have grown by $6.4 \%$ and economy of Lithuania - by $6.2 \%$ 
accordingly. However, the impact of the economic downturn was so strong that real growth rate for 2009 for Ukrainian economy was $-15.1 \%$, for Lithuanian economy $--14.8 \%$. The values of countries' lost income, i.e. economic losses incurred, are presented in Table 3 .

TABLE III

LOST INCOME ESTIMATION

\begin{tabular}{|l|l|l|}
\hline & $\begin{array}{l}\text { Lost income (GDP, \%) } \\
\text { according to calculations } \\
\text { performed by the authors, } \\
\text { pre-crisis tendency }\end{array}$ & $\begin{array}{l}\text { Lost income } \\
\text { (GDP, \%) based } \\
\text { on IMF pre-crisis } \\
\text { tendency }\end{array}$ \\
\hline Ukraine & 30.50 & 26.70 \\
\hline Lithuania & 31.17 & 28.14 \\
\hline
\end{tabular}

With the reference to calculations performed, both Lithuania and Ukraine incurred great losses from the economic crisis. The cost of crisis of 2009 for Lithuania amounted for almost one third of country's GDP (31.7\%), according to IMF forecast $-28.14 \%$. The cost of crisis for Ukraine is $30.5 \%$ of country's GDP (based on the authors' calculations and $26.70 \%$ according to the forecast of IMF). Costs of crisis for both countries are huge.

The reason why Ukraine, the second largest economy of CIS countries, disposing rich natural resources and rather high human potential, incurred such losses is not only the economic instability in the country, but also incessant political instability, which is strongly affecting the economic situation in Ukraine. The main reasons of economic crisis costs for Lithuania are disability to properly manage public finances without creating financial reserves in order to release the country in times of crisis. The country significantly increased public debt, failing to take effective action to reduce it. Adoption of certain macro-economic solutions, such as the reduction of central bank interest rates, implementation of credit expansion, economic stimulation of the budget funds, improving the conditions for business and other measures to stabilize the economic situation in the country, was overdue.

\section{CONCLUSIONS}

The most prominent economic crisis indicators are estimated and analysed. The nature of relations between main macroeconomic indicators is revealed. Determining the state of the economy, GDP is the key indicator, which has an impact on all other macroeconomic indicators.

The crisis has inevitably led to reduction of many main indicators of regional development, to the shrinkage of actual GDP. The presented methodology of economic loss evaluation is based on estimation of potential GDP by considering the trends in actual GDP.

Comparison of economic losses incurred by Lithuania and Ukraine has been performed. Based on the performed calculations, it could be stated that economic crisis of 2007-2009 severely affected the economies of both countries. The values of Lithuania and Ukraine lost income, i.e. economic losses incurred during economic downturn, are very high. The cost of crisis for the Lithuanian economy amounts for almost one third of the country's GDP (31.17\%), for Ukraine $-30.5 \%$ of the country's GDP.

\section{REFERENCES}

[1] Budryte, A., Tursa, L. Valstybès skolos raida, rizika ir priimtinumo lygis. Pinigu studijos, 2002, Nr. 4, p. 20-37.

[2] Burns, A., Mitchell, W. W. Measuring Business Cycles. National Bureau of Economic Research, 1946, New York: NBER. [Online]. Available: http://www.fep.up.pt/investigacao/workingpapers/wp107.pdf. [Accessed: Aug. 26, 2013].

[3] Demirguc-Kunt, A., Detragiache, E.. The Determinants of Banking Crises in Developing and Developed Countries. 1998, IMF Sta_Papers, 45(1), pp. 81-109.

[4] Demirguc-Kunt, A., Detragiache, E., Gupta, P. Inside the crisis: An empirical analysis of banking systems in distress. Journal of International Money and Finance, 2006, 25(5), 702-718. http://dx.doi.org/10.1016/j.jimonfin.2006.04.004

[5] Logan A. The United Kingdoms small banks crisis of the early 1990s: what were the leading indicators of failure?, 2001, Bank of England Working Paper 139.

[6] Angkinand, A. P. Output Loss and Recovery from Banking and Currency Crises: Estimation Issues, manuscript, 2008.

[7] Simonavičienè, A., Užkurytė, L. Pokyčiai darbo rinkoje ekonominio nuosmukio metu: Lietuvos atvejis. Ekonomika ir vadyba. 2009, 14, p. 940-946.

[8] Borio, C., Kennedy, N., Prowse, S. D. Exploring aggregate asset price actuations across countries: measurement, determinants and monetary policy implications. 1994, BIS Economic Papers, 40, April.

[9] Kindleberger. C., Manias, Panics, and Crashes: A History of Financial Crises, 1978, Palgrave Macmillan.

[10] Beržinskienė, D. Model of Population Employment Estimation. Economics, 2005, 44(4), p. 43-49.

[11] Frydl, E. The Length and Cost of Banking Crises. 1999, IMF Working Papers, 99/30.

[12] Prichockytè, F., Vaitkevičius, T., Ruplienè, D., D. Lietuvos, Latvijos ir Estijos ekonomikos perkaitimo galimybiu vertinimas. Ekonomikos ir vadybos aktualijos: septintoji studentu moksliniu darbu konferencija, 2007, Šiauliai: Šiaulių universiteto leidykla, p. 199-205.

[13] F. Westermann, A. Tornell. Boom-Bust Cycles in Middle Income Countries: Facts and Explanation, IMF Staff Papers, 2002, Palgrave Macmillan, vol. 49 (Special i), pages 111-155.

[14] Albaitytè, G. Iššūkiai mokesčiu administravimui ekonomikos nuosmukio salygomis. Public Administration, 2009, 2 (22), p. 63-68.

[15] Blümle, G., Goldschmidt, N. From economic stability to social order: The debate about business cycle theory in the 1920s and its relevance for the development of theories of social order by Lowe, Hayek and Eucken. European Journal of the History of Economic Thought, 2006, Nr. 13 (4), p. 543-570.

[16] Gorton, G. Banking Panics and Business Cycles, Oxford Economic Papers, 1988, 40 pp. 221-55.

[17] Kaminsky, G., Reinhart, C. The Twin Crises: The Causes of Banking and Balance-of-Payments Problems." American Economic Review, 1999, 89(3), pp. 473-500. http://dx.doi.org/10.1257/aer.89.3.473

[18] IMF (2008), Perspectives of World Economic Development. Report. April, 2008.

[19] Impact of the current economic and financial crisis on potencial output. Occasional Papers 49, June 2009. Directorate General for Economic and Financial Affairs. European Economy. 87 p.

[20] Aziz, J., Francesco, C., Ranil, S. Currency Crises: In Search of Common Elements. 2000, IMF Working Papers 00/67.

[21] Lithuanian economic statistics and indicators. [Online]. Available: http://www.economywatch.com/economicstatistics/country/Lithuania/\%20-\%20yearListing/. [Accessed: Sept. 14, 2013].

[22] Bordo, M., Eichengreen, B., Klingebiel, D. and Martinez-Peria, M. S. Is the crisis problem growing more severe?, Economic Policy, Vol. 16, Issue 32, pages 51-82, April 2001. [Online]. Available: http://emlab.berkeley.edu/ eichengr/research/EconomicPolicy.pdf. [Accessed: Aug. 28, 2013].

[23] Dapkus, M., Romikaitytè, B. Verslo ciklai: amortizacijos laikotarpio aspektas. Organizaciju vadyba: sisteminiai tyrimai, 2006, 39, p. 53-65.

[24] Jasienè, M., Čapskas, G.. Palūkanu normu kaitos ir jos veiksniu tyrimas Lietuvoje 1994-2006 m. Verslas: teorija ir praktika, 2008, 9 (1), p. 33-44.

[25] Sicherl, P., Cirjakovićm, J., Remec, M. "S-time-distance perspective: providing new insights of the current crisis from BTS and GDP data", 30th CIRET Conference, New York, October 2010. [Online]. Available: 
https://www.ciret.org/ conferences/newyork_2010/papers/upload/p_43856523.pdf. [Accessed: Sept. 4, 2013].

[26] Cecchetti, S. G., Kohler, M., Upper, C. Financial Crises and Economic Activity, NBER Working Papers 15379, National Bureau of Economic Research, Inc., 2009, August. [Online]. Available: http://www.bis.org/publ/othp05.pdf. [Accessed: Sept. 2, 2013]

[27] Rötheli, T. F.. Business Forecasting and the Development of Business Cycle Theory. History of Political Economy, 2007, Nr. 39 (3), p. 481-510.

[28] Blažytė, V., Norkuvienè, A. Nacionalinio biudžeto pajamu kitimo tendencijos. Ekonomikos ir vadybos aktualijos: septintoji studentu moksliniu darbu konferencija, 2007, Šiauliai: Šiauliu universiteto leidykla, p. 45-54

[29] Pukelienė, V., Glinskienė, R., Beržinskienė, D. Darbo jëgos migracija globalinis aspektas. Economics: Systematic Research. 2007, 1 (2), p. 49-64.

[30] World Economic Outlook (WEO) data (Statistics of the Ukraine), IMF. [Online]. Available: http://www.econstats.com/weo/CUKR.htm. [Accessed: Sept. 14, 2013].

Zaneta Simanaviciene. Habilitated Doctor of Social Sciences, professor at Kaunas University of Technology, Faculty of Economics and Management, the head of the Department of Business Economics.

Expert: 1. Czech Science Foundation; 2. National Center of Science and Technology Evaluation, Ministry of Education and Science, Astana, Republic of Kazakhstan; 3. Research Council of Lithuania; 4. Latvian Council of Science Reviewer and editorial board member:

1. Trends Economics and Management. Brno University of Technology. ISSN 1802-8527. http://www.fbm.vutbr.cz/en/faculty/scientific-journal;

2. Engineering Economics. Kaunas University of Technology. ISSN 1392-2785. http://www.inzeko.ktu.lt/index.php/EE/about/editorialTeam;

3. Economics and Management. Kaunas University of Technology. ISSN 1822-6515. http://www.ecoman.ktu.lt/index.php/Ekv/about/editorialTeam;

4. Leisure Time Research. Kaunas Lithuanian Sport University. ISSN 2345-0339. http://laisvalaikiotyrimai.lsu.lt/index.php/en/.

Research interests: tourism, human resources, social responsibility.

Telephone and e-mail address: +370 681436198, zaneta.simanaviciene@ktu.lt
Oksana Palekiene is a $\mathrm{PhD}$ student at Kaunas University of Technology, Faculty of Economics and Management, Department of Business Economics. Research interests: regional economics, regional policy, economic loss.

Work experience in higher education - 4 years: from 2012 - a lecturer at Kaunas University of Technology. She is actively involved in different kinds of international projects performing proposals and successful project implementation (from 2010 - scientific researcher, junior scientific researcher and project coordinator).

Since 2010 she has published 13 scientific publications.

In 2012 as a PhD student O. Palekiene received a fellowship from the Lithuanian Science Council for her academic achievements.+370 37300589 ,

Telephone and e-mail address: oksana.palekiene@ktu.lt

Illya Khadzhynov graduated from the Donetsk National University in 2001. $\mathrm{PhD}$ degree in economics was earned in 2004, Associate Professor of International Economics Department of the Donetsk National University since 2007, Doctor of Economics from 2013. Major fields of study: international economics and regional sustainable development.

Work experience in higher education - 13 years, including 13 years at the Donetsk National University. Professor Khadzhynov is the vice-dean of the Faculty of Economics of the Donetsk National University.

He has published more than 60 publications, including 9 monographs and more than 40 scientific articles, 1 manual and 2 textbook approved by the Ministry of Education and Science of Ukraine.

Professor Khadzhynov was awarded with the diploma of the Ministry of Education and Science of Ukraine (2008), Gratitude of the Donetsk Oblast State Administration (2012)

E-mail address: abc4cba@mail.ru

\section{Zaneta Simanavičiene, Oksana Palekiene, Illya Khadzinovs. Ekonomisko zaudējumu novērtēšana valstu tautsaimniecībās}

Ekonomiskā lejupslīde ekonomiskās krīzes laikā ietekmē valsts reǵionu sociāli ekonomisko att̄̄stību. Rakstā termins „ekonomiskie zaudējumi” tiek apskatīts kā zaudētais ienākums ekonomiskās krīzes laikā. Aprakstītā metodoloǵija lauj objektīvi novērtēt radušos ekonomiskos zaudējumus un noteikt, kura valsts ir visvairāk cietusi no ekonomiskās krīzes. Metodolog̣ija balstās uz faktiskā IKP dinamikas analīzi. Piedāvātās metodolog̣ijas pielietošana krīzes ekonomisko izmaksu novērtēšanai lauj novērtēt ekonomiskās krīzes pakāpi un ietekmi uz Lietuvas un Ukrainas ekonomisko att̄̄stību.

Pētījuma mērkis: izstrādāt metodoloǵiju ekonomisko zaudējumu novērtēšanai ekonomiskās lejupslīdes laikā.

Pētījuma objekts: ekonomiskie zaudējumi.

Metodes: salīdzinošāa, sistemātiskā, log̣iskā zinātniskās literatūras analīze, apkopošana, matemātiskās un statistiskās metodes.

Secinājumi: tika veikta kompleksa makroekonomisko rādītāju analīze, noteikta to savstarpējāa sakarība. Secināts, ka IKP ir galvenais rādītājs, kurā saplūst un no kura ir atkarīgi visi pārējie rāāîtāji. Krīze neizbēgami ir novedusi pie lielākās dalas reǵionālo att̄̄stību raksturojošo rādīiāju samazināšanās, pirmkārt, faktiskā IKP. Piedāvātā ekonomisko zaudējumu novērtēšanas metodolog̣ija balstās uz potenciālā IKP novērtēšanu saistībā ar faktiskā IKP tendencēm.

\section{Симанавичене Жанета, Палякене Оксана, Хаджинов Илья. Оценка экономических потерь в контексте экономики страны}

Экономический спад оказывает огромное влияние на социально-экономическое развитие регионов страны. В данной научной статье понятие экономические потери рассматривается как величина упущенного дохода в период экономического спада. Представленная методология позволяет объективно оценить понесенные экономические потери и определить, которая из стран наиболее пострадала от экономического кризиса. Методология основана на анализе динамики фактического экономического индикатора ВВП. Внедрение предложенной методологии оценки экономических потерь в период экономического спада помог определить степень и природу влияния экономического кризиса на развитии литовской и украинской национальной экономики.

Основная цель статьи: представить методологию для оценки экономических потерь в период экономического спада.

Объект: экономические потери.

Методы: методы сравнительного, систематического, логического анализа научной литературы, обобщения, а также, математические и статистические были использованы.

Выводы: Проведен комплексный анализ макроэкономических индикаторов, установлена взаимосвязь между ними. Выявлено, что ВВП является ключевым индикатором, в который сводятся и от которого зависят все другие индикаторы. Кризис неизбежно привел к сокращению показаний большинства ведущих индикаторов регионального развития, в первую же очередь, фактического ВВП. Представленная методология оценки экономических потерь основана на оценке потенциального ВВП в соотношении с тенденцией фактического ВВП.

Сравнительный анализ экономических потерь во время экономического спада Литвы и Украины в 2007-2009 года выполнен. Основываясь на проведенных расчетах, экономический кризис 2007-2009 года сильно затронул экономику обеих стран. Величины потерянного дохода Литвы и Украины очень велики. Общая стоимость кризиса для литовской экономики составляет почти треть ВВП страны (31,17 \%), для Украины - 30,5 \% ВВП страны.

This research was funded by a grant (No. TAPLU 09/2012) from the Research Council of Lithuania 